\title{
WOOD CONSTRUCTION - ON THE RENEWAL OF AN ANCIENT ART HOLZBAU - ZUR ERNEUERUNG EINER ALTEN KUNST
}

KARIN RAITH // English translation: Mark Wilch

In recent years, wood has been rediscovered as a building material. Its advantages, such as strength, elasticity and natural beauty, have always been appreciated. However, with resources becoming increasingly scarce, wood is becoming ever more valuable as a renewable raw material and in light of climate change, ever more significant as a reservoir for carbon dioxide. To use wood as a $\mathrm{CO}_{2}$ sink, one must ensure that wooden building components are used for as long as possible. This must be followed by a multi-stage process of down-cycling (cascade use) because the carbon absorbed by wood is released back into the atmosphere through combustion and composting.

The longevity of buildings in a technical, aesthetic and functional sense contributes to climate protection regardless of the building materials involved but is especially effective for wood because of this material's long-term storage of carbon dioxide. Architecture that retains its value is professionally executed and therefore robust and durable. It has lasting appeal because of the quality of its design. Its spatial configuration allows for a multiplicity of interpretations and adaptations to meet changing use requirements. Another method of retaining carbon for as long as possible is the use of modular timber structures that can be easily disassembled and reassembled in other locations or in new arrangements. These systems offer further flexibility, but their reconfiguration calls for construction measures, which, in turn, require the input of energy and resources.

\section{NATURAL FORM}

Standard wood products have been used for decades in building construction. The standardization of these wood materials follows primarily an industrial, mechanistic logic from a different era, when the processing of a large number of identical parts guar-
In den letzten Jahren wurde Holz als Baumaterial wiederentdeckt. Seine Vorzüge wie Festigkeit, Elastizität und seine natürliche Schönheit wurden schon immer geschätzt, doch mit zunehmender Ressourcenverknappung wird Holz als nachwachsender Rohstoff immer wertvoller und gewinnt aufgrund des Klimawandels auch als Kohlendioxidspeicher an Bedeutung. Um Holz als $\mathrm{CO}_{2}$-Senke zu nutzen, muss für eine möglichst langfristige Verwendung der hölzernen Bauteile und danach für ein mehrstufiges Downcycling (Kaskadennutzung) gesorgt werden, denn durch Verbrennung (,energetische Verwertung $)$ und Kompostierung wird der vom Holz aufgenommene Kohlenstoff wieder an die Atmosphäre abgegeben.

Das Prinzip der Langlebigkeit von Bauten in technischer, ästhetischer und funktioneller Hinsicht trägt zwar unabhängig von den verwendeten Baustoffen zum Klimaschutz bei, ist im Holzbau aber wegen der langfristigen Kohlenstoffspeicherung im Material besonders wirkungsvoll. Wertbeständige Architektur ist fachgerecht ausgeführt und daher robust und dauerhaft, sie bleibt aufgrund ihrer gestalterischen Qualität langfristig attraktiv, und die räumliche Konfiguration erlaubt vielfältige Interpretationen und Anpassungen an veränderte Nutzungsanforderungen. Eine andere Methode, Kohlenstoff möglichst lang zu binden, ist die Verwendung modularer Holzbauten, die leicht zerlegt und an anderen Orten oder in neuen Anordnungen wieder zusammengefügt werden können. Solche Systeme bieten weitere Flexibilität, erfordern aber für die Rekonfiguration Baumaßnahmen, die selbst wieder Energie und Ressourcen benötigen.

\section{NATÜRLICHE FORM}

Seit Jahrzehnten wird mit Standard-Holzprodukten gebaut. Diese Vereinheitlichung der Holzwerkstoffe folgt primär einer industriellen, mechanistischen Logik und stammt aus einer Epoche, in der die Verarbeitung einer großen Anzahl gleicher Teile niedrige Kosten garantierte. Das Holz wird 
anteed low costs. Wood is robbed of its individuality, standardized and homogenized in order to control its load-bearing behavior more effectively with conventional calculation methods and to use it for serial construction. The paradox here is that this type of standardized material must not only serve repetitive construction tasks such as those assigned to building mass housing but also individualistic architecture - the construction of buildings that are unusual, unique and striking. But might not the opposite tack be more logical? Although classifying and standardizing this living raw material into standard cut boards and panels facilitates modular construction, this approach utilizes only a fraction of wood's potential. Waste wood goes into particle board or paper production, a use that also falls far short of fully tapping this material's capacity. What a richness of forms, structures and textures is lost in the process!

Traditional Japanese wood construction, an art with a long history, reveals another attitude that could give fresh impetus to renewing the (Western) practices common today. Wood is revered in Japanese culture. The respect for this natural material is rooted in Shintō, a religious tradition that views all things in the natural world as inhabited by spirits (kami) and therefore also honors trees as living organisms. The rules that have been passed down obligate artisans to use a tree in such a way that it continues to exist for a long time, ideally as an aesthetic object or building component that is appreciated over the course of centuries. ${ }^{1}$ To be able to ascertain the suitable function and the appropriate place for any given tree in an architectural structure, its unique qualities must be recognized - its 'personality', as Tsunekazu Nishioka once said. In Japanese carpentry, he was a highly respected master among the miyadaiku, the temple and shrine carpenters, and headed up the restoration and reconstruction work on the oldest Buddhist temple complexes in Japan, Höryzu-ji and Yakushi-ji. ${ }^{2}$

Respecting the personality of wood meant creating continuity between its natural, living state and its use as part of a building. ${ }^{3}$ Wood was incorporated into the structure with the same directional orientation it had at the original site where it grew. This practice was applied in particular when trees were converted into vertical structural members, to columns and posts. For instance, a post cut out of the windward side of the tree was placed on the windward side of the building, with the root end at the bottom and seiner Individualität beraubt, normiert und homogenisiert, um sein Tragverhalten mit den herkömmlichen Berechnungsmethoden besser kontrollieren zu können und um es für serielles Bauen zu nutzen. Paradox ist, dass solcherart standardisiertes Material nicht nur repetitiven Bauaufgaben wie etwa dem Massenwohnungsbau, sondern auch individualistischer Architektur zu dienen hat - der Konstruktion des Außergewöhnlichen, Einzigartigen und Aufsehenerregenden. Doch wäre es umgekehrt nicht sinnvoller? Die Klassifikation und Vereinheitlichung des lebendigen Rohstoffs zu Standard-Schnitt- und -Plattenware erleichtert zwar das modulare Bauen, doch es wird nur ein Bruchteil des Material-Potenzials genutzt und das Restholz unter seiner Leistungsfähigkeit in der Spanplatten- oder Papiererzeugung ,verwertet ${ }^{\dagger}$. Welcher Reichtum an Formen, Strukturen und Texturen geht dabei verloren!

Der traditionelle japanische Holzbau, eine Kunst mit einer langen Geschichte, offenbart eine andere Haltung, die Impulse zu einer Erneuerung der heute gängigen (westlichen) Praxis geben könnte. Holz genießt in der japanischen Kultur große Wertschätzung. Der Respekt vor dem Naturstoff wurzelt im Shintō, einer religiösen Tradition, die alle Naturerscheinungen als beseelt erachtet und daher auch die Bäume als lebendige Organismen ehrt. Die überlieferten Regeln verpflichten Handwerker*innen, einen Baum so zu verwenden, dass er lange fortbesteht, idealerweise als ein ästhetischer Gegenstand oder Bauteil, der über Jahrhunderte geschätzt wird. ${ }^{1}$ Damit die passende Funktion und der angemessene Platz des individuellen Baums im architektonischen Gefüge gefunden werden können, müssen seine Eigenarten erkannt werden - seine ,Persönlichkeit', wie das Tsunekazu Nishioka nannte, der von der japanischen Fachwelt hochverehrte Meister der Zunft der Tempelschreiner (miyadaiku) und Leiter der Restaurierungs- und Rekonstruktionsarbeiten an den ältesten buddhistischen Tempelanlagen Japans, Hōryz̄ji und Yakushi-ji. ${ }^{2}$

Die Persönlichkeit des Holzes zu respektieren hieß, eine Kontinuität zwischen seinem natürlichen, lebendigen $\mathrm{Zu}$ stand und seiner Verwendung als Teil eines Gebäudes zu schaffen. ${ }^{3}$ Es wurde in der gleichen Lagebeziehung zu den Himmelsrichtungen eingebaut, wie es an seinem ursprünglichen Standort gewachsen war. Das galt insbesondere für die Verarbeitung der Bäume zu vertikalen Bauteilen, zu Säulen und Pfosten. Beispielsweise wurde ein aus der Wetterseite des Baumes geschnittener Pfosten an der Wetterseite des Gebäudes positioniert, das Wurzelende unten, das Kronenende oben. ${ }^{4}$ So konnten die Eigenarten der Mikrostruktur, die in Reaktion auf die Gravitation, die geologischen und klimatischen Bedingungen des Wuchsorts entstanden waren, ihr 
the crown end at the top. ${ }^{4}$ This approach unlocked the full potential of the microstructure's unique properties, which came about in response to gravity and to the geological and climatic conditions at the growth site. Different kinds of wood were used in accordance with their typical properties, but anomalies (known as 'timber defects' in the parlance of the traditional construction industry) such as reaction wood, twisted growth, or forked growth were also turned into virtues and used for special purposes. If incorporated as a load-bearing member with a natural camber or shallow arch, a crooked stem is more resistant to vertically acting loads than a straight one. This intelligent use of wood in accordance with its specific natural advantages is not only found in elitist temple construction but was also customary in vernacular architecture (Fig. 1), in other words in a realm where raw materials had to be used sparingly because of the precarious conditions of life. In pre-industrial times, knee timber was also coveted in the West for use in special elements, for example, for ribs in shipbuilding, for the hoops forming the tread of a wheel in the wheelwright trade, for stair stringers, and also in furniture construction until Thonet invented the bentwood process. In the mass timber construction of recent decades, timber defects were considered undesirable. volles Potenzial entfalten. Unterschiedliche Holzarten wurden ihren typischen Eigenschaften entsprechend eingesetzt, aber auch Anomalien (in der Diktion der konventionellen Bauindustrie ,Holzfehler ${ }^{c}$ ) wie Reaktionsholz, Drehwuchs oder Gabelwuchs in Vorzüge verwandelt und für besondere Zwecke genutzt. Ein krummschäftiger Stamm, als Träger mit natürlicher Überhöhung oder flacher Bogen eingebaut, ist widerstandsfähiger gegenüber vertikal wirkenden Lasten als ein gerader. Diese intelligente Verwendung des Holzes gemäß seinen spezifischen natürlichen Vorteilen ist nicht nur in der elitären Tempelbaukunst zu finden, sondern war auch in der vernakulären Architektur üblich (Abb. 1), also in einem Bereich, wo aufgrund prekärer Lebensbedingungen mit Rohstoffen sparsam umgegangen werden musste. Auch im Westen war in vorindustrieller Zeit Krummholz für besondere Elemente begehrt, etwa für die Spanten im Schiffsbau, für Radreifen in der Wagnerei, für Treppenwangen und bis zur Erfindung des Bugholzes durch Thonet ebenso im Möbelbau. Für den Massen-Holzbau der letzten Jahrzehnte waren Holzfehler unerwünscht.

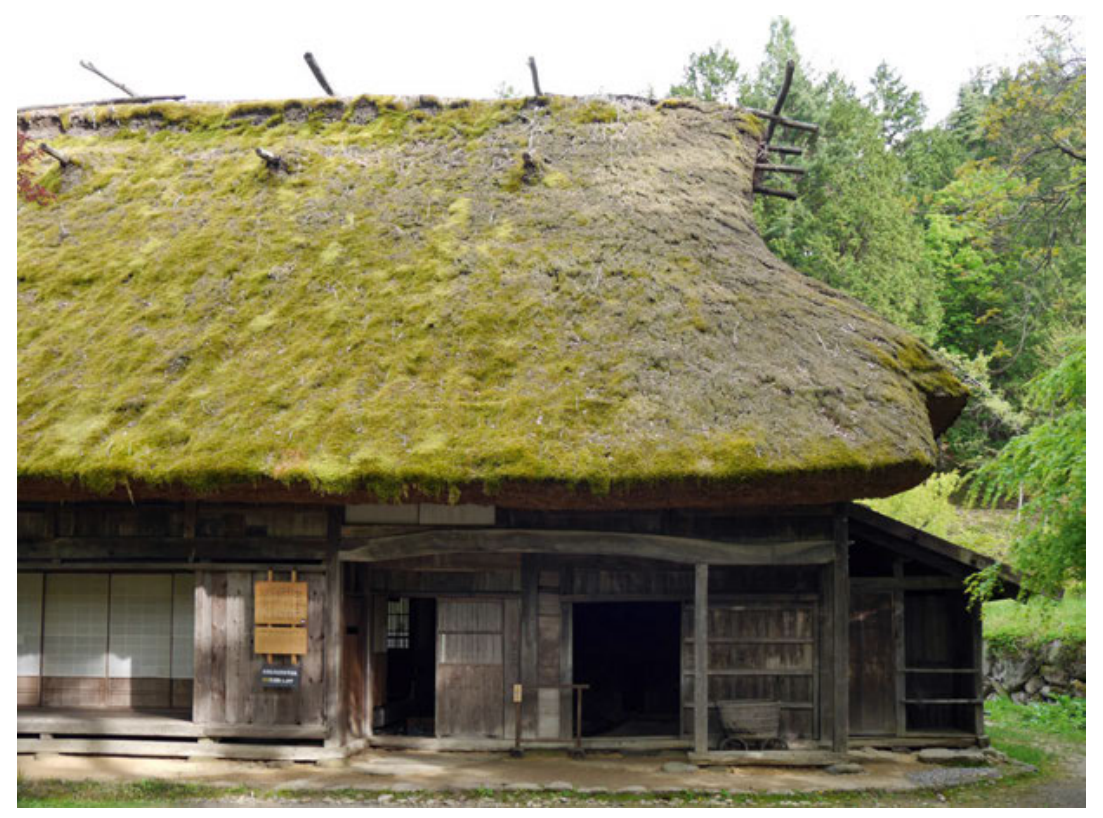

\ Fig. 1 | Abb. 1:

Michigami House, Hida no sato (Hida Folk Village), Hida, Gifu prefecture, Japan, 18th century.

Photo $\odot$ Karin Raith 
Yet we no longer have to produce identical building elements in large series to build economically. Digitalization opens up new possibilities for designing more freely and for updating traditional knowledge. It allows for individualized fabrication and the use of wood parts that deviate from rectilinear geometries. Carpenters on a par with Nishioka are few and far between nowadays, that is, carpenters with the experience and intuition to sense the inner structure of a tree or piece of wood and to utilize it with the full virtuosity of their craft. Yet today trees can be scanned and captured in 3D models; automated digital searches can help determine the ideal use for each wood component in the structure of a building.

With GPS, laser measurement, and RFID (radio-frequency identification), wood can be tracked with precision, from its place of harvest in the forest through all the processing steps to its place of installation within the building. As in the highly advanced Japanese building tradition for sacred architecture, these technologies even let us maintain the connection between the position of the wooden element in the building and the original growth site of the tree in order to make optimum use of the element's individual capacity. Once the specific properties of each individual building component are captured in a data model, it is easier to reuse the component later in a different context.

The fact that the load-bearing behavior of irregular wood geometries and natural forms of growth can also be calculated facilitates the use of deciduous trees, which will withstand the effects of climate change better than their coniferous counterparts. Thus far, their stems have only been used in the form of glued laminated timber (glulam), largely for postand-beam construction in facades. The crowns have not been economically usable for wood construction due to their complex geometry.

\section{THE ART OF JOINERY}

Stone construction always played a subordinate role in Japan, so all attention was directed at refining wood construction. This focus resulted in interlocking wood joints (kigumi) of unbelievable diversity and ingenuity. They have also proved their mettle in the frequent earthquakes and typhoons that occur there and under heavy snow loads. For cost reasons, metal connectors were largely dispensed with. ${ }^{5}$ What fascinates us today about these all-wood joints is, on the
Doch wir müssen nicht mehr gleiche Bauelemente in großer Serie produzieren, um wirtschaftlich zu bauen. Die Digitalisierung eröffnet neue Möglichkeiten für freiere Gestaltung und für die Aktualisierung des traditionellen Wissens. Sie erlaubt eine individualisierte Fabrikation und die Verwendung von Holzteilen, die von der geradlinigen Geometrie abweichen. Es gibt zwar kaum mehr Zimmermeister*innen, die wie Nishioka die Erfahrung und Intuition besitzen, die innere Struktur eines Baumes oder Holzstücks zu erfühlen und sie mit handwerklicher Virtuosität zu nutzen, doch heute können Bäume gescannt und in 3D-Modellen erfasst werden, mit automatisierten digitalen Suchläufen kann die ideale Verwendung für jeden Holzteil in der Baustruktur ermittelt werden.

Mittels GPS, Laservermessung und RFID (radio-frequency identification) ist das Holz vom Ernteort im Wald durch alle Verarbeitungsschritte bis zum Einbauort im Gebäude präzise verfolgbar. Damit könnte sogar - wie in der hochentwickelten japanischen Sakralbautradition - der Bezug zwischen der Position des Holzelements im Gebäude und dem ursprünglichen Wuchsort des Baums beibehalten werden, um das Holz entsprechend seiner individuellen Leistungsfähigkeit optimal einzusetzen. Sind die spezifischen Eigenschaften jedes einzelnen Bauteils auch in einem Datenmodell erfasst, dann vereinfacht dies seine spätere Wiederverwendung in einem anderen Kontext.

Dass auch das Tragverhalten irregulärer Holz-Geometrien und natürlicher Wuchsformen berechnet werden kann, erleichtert die Verwendung von Laubbäumen, die den Klimawandel besser als Nadelbäume überstehen werden. Bisher wurden deren Stämme nur in Form von Brettschichtholz vor allem für Pfosten-Riegel-Konstruktionen im Fassadenbau eingesetzt, die Kronen waren wegen ihrer komplexen Geometrie für den Holzbau bisher nicht ökonomisch nutzbar.

\section{FÜGEKUNST}

Da der Steinbau in Japan immer eine untergeordnete Rolle spielte und alle Aufmerksamkeit auf die Verfeinerung des Holzbaus gerichtet war, entwickelte sich eine unglaubliche Vielfalt und Raffinesse der Holzverbindungen (kigumi), die ihre Leistungsfähigkeit auch bei den häufigen Erdbeben und Taifunen oder unter hohen Schneelasten bewiesen. Aus Kostengründen wurde weitgehend auf metallische Verbindungsmittel verzichtet. ${ }^{5}$ Heute faszinieren uns diese einstofflichen Verbindungen einerseits wegen ihrer komplexen, durchdachten Geometrie, andererseits wegen der Vorteile der Monomaterialität in der Kreislaufwirtschaft (Abb. 2). Die meisten kigumi-Verbindungen sind lösbar und erlauben eine zerstörungsfreie Weiterverwendung der Bauteile, doch 
one hand, their complex and carefully conceived geometry and on the other hand, the advantages of their mono-materiality in the circular economy (Fig. 2). Most kigumi joints can be disassembled, allowing for the non-destructive reuse of the building components. Even with joints that cannot be disassembled, the problem of separating the materials by type is eliminated.

With the design technique known as kiwari-jutsu (literally: wood dividing system), the proportions between the individual building components were determined and their reciprocal relationships with each other were systematized, also with regard to aesthetics. ${ }^{6}$ Creativity tended to flow into perfecting the building components and their construction rather than into achieving individualistic architectural designs. Residential buildings were modular compositions with a universal structural arrangement that was based on a grid of supports spaced one ken apart. This unit of measure varied somewhat with locality and over time until it was gradually regimented. ${ }^{7}$ Diversity arose from the functional flexibility of the modules. This kind of modularity, which creates order without giving rise to monotony, would also be possible in contemporary wood construction. Parametric design tools facilitate work with individual components and enable combinatorics and a creation of variants to approach an ideal structure. Could wood in its differentiated, non-homogeneous form not be used for modular, generic and open-use architecture as well? selbst im Falle unlösbarer Verbindungen entfällt das Problem der sortenreinen Trennung der Materialien.

Mit der Entwurfstechnik kiwari-jutsu (wörtlich: Holzteilungstechnik) wurden die Proportionen zwischen einzelnen Bauteilen bestimmt und ihre wechselseitigen Beziehungen auch in ästhetischer Hinsicht geregelt und systematisiert. ${ }^{6}$ Die Kreativität floss eher in die Perfektion der Bauteile und ihrer Fügung als in die individuelle Gestaltung der Architektur. Die Wohnhäuser waren modulare Kompositionen mit einer universellen strukturellen Ordnung, basierend auf einem Stützenraster im Abstand von einem ken, dessen Größe örtlich und zeitlich ein wenig variierte und erst nach und nach reglementiert wurde. ${ }^{7}$ Vielfalt entstand durch die funktionelle Flexibilität der Module. Eine solche Modularität, die Ordnung erzeugt, ohne Eintönigkeit aufkommen zu lassen, wäre auch im zeitgenössischen Holzbau möglich. Parametrische Entwurfswerkzeuge erleichtern das Arbeiten mit individuellen Komponenten, sie erlauben eine Kombinatorik und Variantenbildung zur Annäherung an eine Idealstruktur. Könnte damit das Holz nicht auch in seiner differenzierten, inhomogenen Form für modulare, generische und nutzungsoffene Architektur verwendet werden?

1 Brown, A. (1995): The Genius of Japanese Carpentry. Secrets of an Ancient Craft, Tokyo: Tuttle Publishing: 21.

2 ibid., 55.

3 ibid.

4 ibid., 56.

5 en It is a myth that traditional wood joinery in Japan made do without any metal parts at all. Even the oldest temples have nails, albeit few in number, which were used for additionally securing the wood joints.

de Dass die traditionelle Holzfügekunst Japans völlig ohne Metallteile auskam, ist ein Mythos - es finden sich auch in den ältesten Tempelbauten Nägel, die zur zusätzlichen Sicherung der Holzverbindungen verwendet wurden, allerdings nur in geringer Anzahl.

6 "It is based on a similar idea to that of modern programming in the sense that it generates a string of optimal proportions obtained by multiplying a standard dimension with a coefficient ( $\mathrm{Y}=\mathrm{aX})$." Tadanori, S. (2018):, "Secret Books of Carpentry Techniques", in: Takahide, T. et al. (eds.): Japan in Architecture. Genealogies of its Transformation, Tokyo: Shimoda Yasunari: 45. "In architecture the dimensions of the rafters taruki are taken as the basic unit, and the proportions of the bays, projecting eaves and so on, are then calculated according to a formula based on the size of the rafter." (JAANUS, Japanese Architecture and Art Net Users System, http://www.aisf.or.jp/ jaanus/deta/k/kiwari.htm, December 17, 2020). 


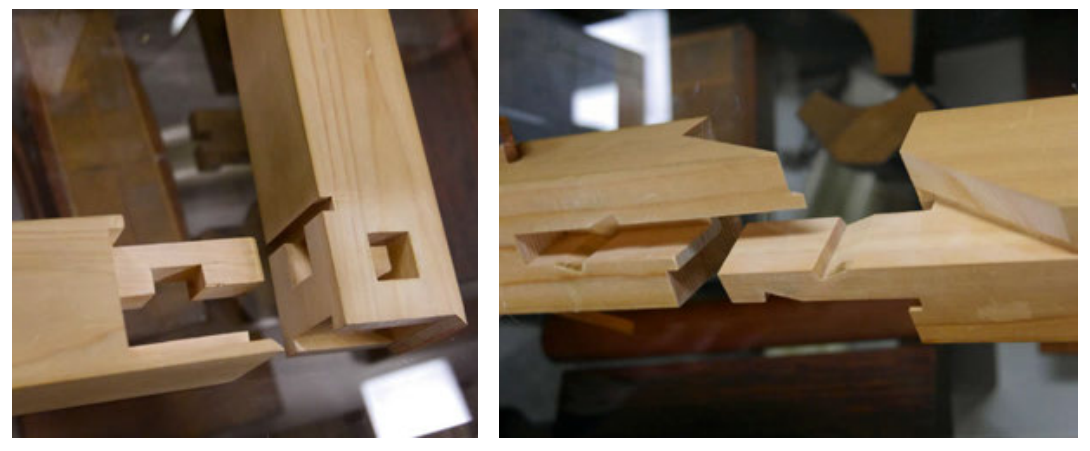

4 Fig. 2 | Abb. 2:

Examples from the collection of wood joints of Shimizu Corporation furniture carpentry, Tokyo.

Photos $\odot$ Karin Raith
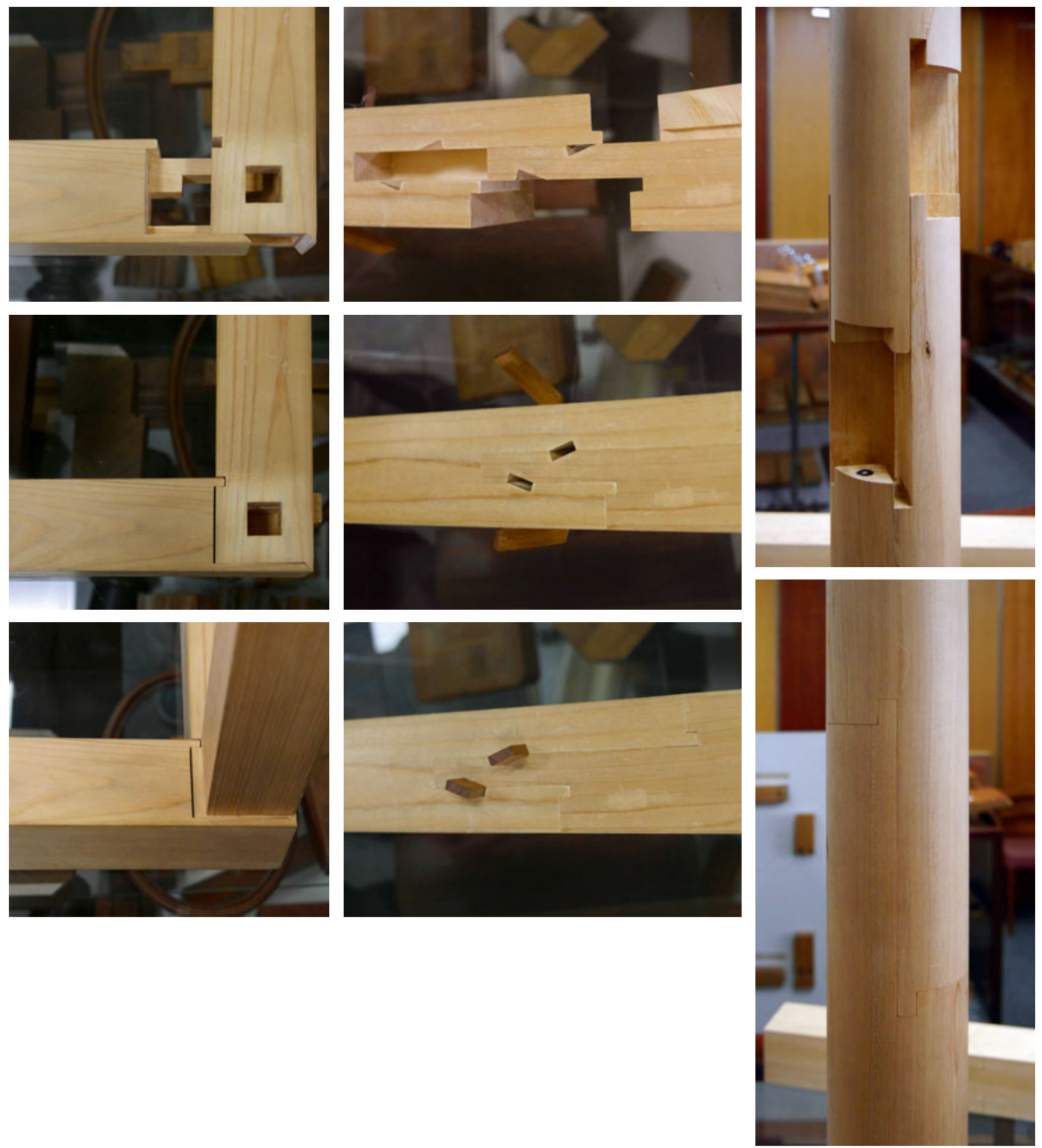